\title{
Nonlinear responses of soil nitrous oxide emission to multi-level nitrogen enrichment in a temperate needle-broadleaved mixed forest in Northeast China
}

\author{
Shulan Cheng a,b ${ }^{\text {, }}$ Lei Wang a,b ${ }^{\text {, }}$ Huajun Fang ${ }^{\text {a,* }}$, Guirui Yu ${ }^{a}$, Xueming Yang ${ }^{c}$, Xiaoyu Li ${ }^{\text {a }}$, Gaoyue Si ${ }^{\text {b }}$, Jing Geng ${ }^{\text {a }}$, \\ Shun $\mathrm{He}^{\mathrm{b}}$, Guangxia Yu ${ }^{\mathrm{b}}$ \\ ${ }^{a}$ Key Laboratory of Ecosystem Network Observation and Modeling, Institute of Geographical Sciences and Natural Resources Research, Chinese Academy of Sciences, Beijing 100101, China \\ ${ }^{\mathrm{b}}$ University of Chinese Academy of Sciences, Beijing 100049, China

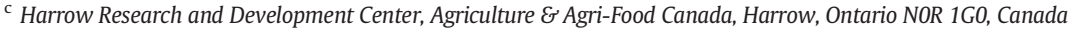

\section{A R T I C L E I N F O}

\section{Article history:}

Received 7 July 2015

Received in revised form 14 July 2016

Accepted 8 August 2016

Available online 12 August 2016

\section{Keywords:}

Atmospheric $\mathrm{N}$ deposition

Soil $\mathrm{N}_{2} \mathrm{O}$ flux

Soil dissolved N

Nonlinear responses

Temperate needle-broadleaved mixed forest

\begin{abstract}
A B S T R A C T
The responses of nitrous oxide $\left(\mathrm{N}_{2} \mathrm{O}\right)$ emission from forest soils to increasing atmospheric nitrogen $(\mathrm{N})$ deposition are controversial. In this study, our objectives were to explore the response curves of soil $\mathrm{N}_{2} \mathrm{O}$ flux to multilevel $\mathrm{N}$ inputs, as well as to examine the key factors dominating the changes in soil $\mathrm{N}_{2} \mathrm{O}$ emission caused by $\mathrm{N}$ enrichment in the temperate needle-broadleaved mixed forest, Northeast China. The study consists of nine levels of urea addition $\left(0,10,20,40,60,80,100,120,140 \mathrm{~kg} \mathrm{~N} \mathrm{ha}^{-1} \mathrm{yr}^{-1}\right)$ with 4 replicates for each treatment. Soil $\mathrm{N}_{2} \mathrm{O}$ fluxes were monitored weekly using the static chamber and gas chromatograph technique. $\mathrm{NH}_{4}^{+}-\mathrm{N} \mathrm{NO}_{3}^{-}-\mathrm{N}$, total dissolved N (TDN), dissolved organic N (DON), and auxiliary variables (soil temperate and moisture in 0-10 cm depth) were measured at the same frequency to examine the regulation of $\mathrm{soil}_{2} \mathrm{O}$ flux. The results showed that high rates of urea inputs $\left(>60 \mathrm{~kg} \mathrm{~N} \mathrm{ha}^{-1} \mathrm{yr}^{-1}\right)$ significantly increased soil $\mathrm{NO}_{3}^{-}-\mathrm{N}$ concentrations in litter layer and mineral layer ( $0-10 \mathrm{~cm}$ depth) by $120-180 \%$ and $56.4-84.6 \%$, respectively. Soil $\mathrm{N}_{2} \mathrm{O}$ flux increased exponentially with increase in the rates of urea addition by $194 \%$ to $334 \%$ for the 60 to $140 \mathrm{~kg} \mathrm{~N} \mathrm{ha}^{-1} \mathrm{yr}^{-1}$ treatments relative to the control. The critical level of $\mathrm{N}$ input for the significant alternation of soil $\mathrm{N}$ accumulation and $\mathrm{N}_{2} \mathrm{O}$ emission was approximately $70 \mathrm{~kg} \mathrm{~N} \mathrm{ha}^{-1} \mathrm{yr}^{-1}$. The changes in soil $\mathrm{N}_{2} \mathrm{O}$ flux elicited by $\mathrm{N}$ addition were positively related to those of soil $\mathrm{NO}_{3}^{-}-\mathrm{N}$ and soil moisture contents. These results suggest that exogenous $\mathrm{N}$ input at the rate below the critical load will not significantly promote soil $\mathrm{N}_{2} \mathrm{O}$ emission over the short term, which is favorable to carbon sequestration of the temperate needle-broadleaved mixed forest, Northeast China.
\end{abstract}

(c) 2016 Elsevier B.V. All rights reserved.

\section{Introduction}

Nitrous oxide $\left(\mathrm{N}_{2} \mathrm{O}\right)$ is the third most important anthropogenic greenhouse gas and the largest remaining anthropogenic source of stratospheric ozone depleting substances (Stocker et al., 2013). The global source strength of $\mathrm{N}_{2} \mathrm{O}$ is estimated to be $17.7 \mathrm{Tg} \mathrm{N} \mathrm{yr}^{-1}$, with agriculture and soils under natural vegetation contributing 53.1\% (Hirsch et al., 2006; Solomon, 2007). $\mathrm{N}_{2} \mathrm{O}$ is mainly removed from the atmosphere via a series of processes such as photolysis, chemical transformation, and wet and dry deposition. The global sink strength of $\mathrm{N}_{2} \mathrm{O}$ is estimated to be $12.6 \mathrm{Tg} \mathrm{N} \mathrm{yr}^{-1}$ (Solomon, 2007). Over the past 250 years, anthropogenic $\mathrm{N}$ deposition has increased by about three times (Galloway et al., 2008), which leads to an increase in carbon (C) sequestration in terrestrial ecosystems $\left(20-470 \mathrm{~kg} \mathrm{C} \mathrm{kg}^{-1} \mathrm{~N}\right.$, Högberg, 2007; Magnani et al., 2007; Reay et al., 2008; Sutton et al., 2008; de

\footnotetext{
* Corresponding author at: 11A Datun Road, Chaoyang District, Beijing 100101, China. E-mail address: fanghj@igsnrr.ac.cn (H. Fang).
}

Vries et al., 2009; Thomas et al., 2010; Templer et al., 2012; Pinder et al., 2013). However, increasing $\mathrm{N}$ deposition also accelerates soil $\mathrm{N}_{2} \mathrm{O}$ emission and inhibits soil methane $\left(\mathrm{CH}_{4}\right)$ uptake (Lu et al., 2011a, 2011b). If the effects on soil $\mathrm{CH}_{4}$ uptake and $\mathrm{N}_{2} \mathrm{O}$ emission are considered, the $\mathrm{C}$ sink caused by exogenous $\mathrm{N}$ inputs can be offset by $53 \%$ to 76\% (Liu and Greaver, 2010). Thus, deep understanding of the responses of soil $\mathrm{N}_{2} \mathrm{O}$ emission to increasing $\mathrm{N}$ deposition is crucial to reduce the uncertainty of $\mathrm{C}$ sink estimation in terrestrial ecosystems.

Soil $\mathrm{N}_{2} \mathrm{O}$ is produced by denitrification under anaerobic conditions and by nitrification under aerobic conditions (Davidson et al., 2000). Soil $\mathrm{N}_{2} \mathrm{O}$ emission is influenced by soil temperature, moisture, soil $\mathrm{N}$ availability, dissolved organic C (DOC), and pH (Florinsky et al., 2004; Rowlings et al., 2012). Theoretically, there is greater emissions of $\mathrm{N}_{2} \mathrm{O}$ under elevated $\mathrm{N}$ deposition or $\mathrm{N}$ application due to increased availability of $\mathrm{NH}_{4}^{+}$and $\mathrm{NO}_{3}^{-}$for both nitrification and denitrification (Davidson, 2009). However, evidences from various forest ecosystems show that simulated N deposition increases (Kim et al., 2012), decreases (Skiba et al., 1999) or does not change (Borken and Beese, 2005) soil $\mathrm{N}_{2} \mathrm{O}$ 
emission. Overall, although $\mathrm{N}$ addition tends to promote soil $\mathrm{N}_{2} \mathrm{O}$ emission (Lu et al., 2011a), the curves of soil $\mathrm{N}_{2} \mathrm{O}$ flux responded to the rates of $\mathrm{N}$ addition are diverse including linear (Borken and Beese, 2005; Liu et al., 2012), exponential growth (Ambus et al., 2006; Liu et al., 2013b), and quadratic (McSwiney and Robertson, 2005), etc. These contradictory results may be attributed to the differences in the initial $\mathrm{C}$ and $\mathrm{N}$ status, the microbial community composition, and the type and rate of $\mathrm{N}$ application (Kim et al., 2013). Response of soil $\mathrm{N}_{2} \mathrm{O}$ emission to $\mathrm{N}$ addition depends on the stages of $\mathrm{N}$ saturation (Aber et al., 1998), but the critical levels of $\mathrm{N}$ inputs or soil available $\mathrm{N}$ contents are not quantified for most terrestrial ecosystems.

Tropical forest soils are responsible for $14-23 \%$ of global $\mathrm{N}_{2} \mathrm{O}$ emissions (Solomon, 2007), whereas the boreal and temperate forest soils are generally considered to contribute little to atmospheric $\mathrm{N}_{2} \mathrm{O}$ accumulation (Werner et al., 2007; Koehler et al., 2009). However, both warming and chronic $\mathrm{N}$ deposition increase the $\mathrm{N}$ availability in the high-latitude forest ecosystems, thereby significantly promotes soil $\mathrm{N}_{2} \mathrm{O}$ emission (Repo et al., 2009; Elberling et al., 2010). China is located at the center of the global $\mathrm{N}$ deposition, and the average $\mathrm{N}$ deposition rate is estimated to range between 12.9 and $21.1 \mathrm{~kg} \mathrm{~N} \mathrm{ha}^{-1} \mathrm{yr}^{-1}$ (Lü and Tian, 2007; Liu et al., 2013a; Jia et al., 2014). Inorganic $\mathrm{N}^{\left(\mathrm{NH}_{4}^{+}\right.}$ and $\mathrm{NO}_{3}^{-}$) and organic $\mathrm{N}$ account for $73 \%$ and $27 \%$ of the total $\mathrm{N}$ deposition, respectively (Zhu et al., 2015). In the past decades, mineral $\mathrm{N}$ fertilizers (e.g., $\mathrm{NH}_{4} \mathrm{NO}_{3}, \mathrm{NH}_{4} \mathrm{Cl}$, or $\mathrm{NaNO}_{3}$ ) are often applied to simulate the effects of $\mathrm{N}$ deposition on soil $\mathrm{N}_{2} \mathrm{O}$ production and emission in some temperate and subtropical forests (Zhang et al., 2008; Wang et al., 2014; Bai et al., 2014). However, little information can be available about the effects of organic $\mathrm{N}$ input on soil $\mathrm{N}$ accumulation and soil $\mathrm{N}_{2} \mathrm{O}$ emission in the $\mathrm{N}$-poor temperate forests.

In this study, we defined the critical load as the level of $\mathrm{N}$ deposition (Bobbink and Hettelingh, 2011), below which soil $\mathrm{N}_{2} \mathrm{O}$ flux was not significantly impacted. Before the $\mathrm{N}$ input amount adequately supplied plant $\mathrm{N}$ demand, $\mathrm{N}$ addition would result in low soil $\mathrm{N}_{2} \mathrm{O}$ emission; after that, soil $\mathrm{N}_{2} \mathrm{O}$ flux could be greatly stimulated and might exhibit threshold responses to $\mathrm{N}$ addition rates. The different stages of soil $\mathrm{N}_{2} \mathrm{O}$ flux response to $\mathrm{N}$ addition were closely related to the availability of nitrification and denitrification substrates. Thus, we hypothesized that organic $\mathrm{N}$ addition would not promote $\mathrm{N}_{2} \mathrm{O}$ emission from the $\mathrm{N}$ poor temperate forest soils until dissolved $\mathrm{N}$ content in soils or $\mathrm{N}$ addition rate exceeded their critical values. We also hypothesized that the changes in soil $\mathrm{N}_{2} \mathrm{O}$ emission fluxes caused by $\mathrm{N}$ addition could be explained by the changes in soil dissolved $\mathrm{N}$ contents. Our objectives in this study were: (1) to investigate the changes in dissolved $\mathrm{N}$ contents, $\mathrm{N}_{2} \mathrm{O}$ flux, soil temperate, and soil moisture among different experimental treatments; and (2) to elucidate those factors which are responsible for the changes in $\mathrm{N}_{2} \mathrm{O}$ emission from the temperate forest soils induced by $\mathrm{N}$ addition.

\section{Materials and methods}

\subsection{Study site and experimental design}

This study was conducted in an old-growth broadleaf and Korean pine mixed forest, located at Changbaishan Forest Ecosystem Research Station (CFERS, $127^{\circ} 38^{\prime} \mathrm{E}, 41^{\circ} 42^{\prime} \mathrm{N}$ ) in Jilin province, China. Longterm mean annual temperature and precipitation are $3.6{ }^{\circ} \mathrm{C}$ and $700 \mathrm{~mm}$, respectively. The soil is classified as Eutric Cambisol (FAO classification) with bulk density of $0.53 \mathrm{~g} \mathrm{~cm}^{-3}$, total $\mathrm{C}$ of $156.6 \mathrm{~g} \mathrm{~kg}^{-1}$, total $\mathrm{N}$ of $7.17 \mathrm{~g} \mathrm{~kg}^{-1}$, total $\mathrm{P}$ of $0.97 \mathrm{~g} \mathrm{~kg}^{-1}$, $\mathrm{pH}$ of 5.85 , and $\mathrm{C} / \mathrm{N}$ ratio of 21.84 in 0-20 cm layer (Wang et al., 2012). The dominant tree species are Pinus koraiensis, Fraxinus mandshurica, Quercus mongolica, and Tilia amuresis.

The experiment used a completely randomized design with 36 plots ( $15 \mathrm{~m} \times 15 \mathrm{~m}$ each) arranged for nine $\mathrm{N}$ enrichment treatments (4 replications). Relatively flat underlying surface was selected to prepare plots, and each plot contained pine and other broadleaf species as many as possible. The distance between any two adjacent plots was $>10 \mathrm{~m}$. $\mathrm{N}$ was added as solid urea $\left(\mathrm{CO}\left(\mathrm{NH}_{2}\right)_{2}\right)$ once a month, and the treatments started since 2013. Referring to the actual atmospheric $\mathrm{N}$ deposition of Changbai Mountain (10.79 $\mathrm{kg} \mathrm{N} \mathrm{ha}^{-1} \mathrm{yr}^{-1}$, Zhu et al., 2015) and the highest levels of $\mathrm{N}$ deposition in China (117 $\mathrm{kg} \mathrm{N} \mathrm{ha}^{-1} \mathrm{yr}^{-1}, \mathrm{He}$ et al., 2007), we fertilized at eight levels of $\mathrm{N}(10,20,40,60,80,100,120$, and $\left.140 \mathrm{~kg} \mathrm{~N} \mathrm{ha}^{-1} \mathrm{yr}^{-1}\right)$, and a control treatment $\left(0 \mathrm{~kg} \mathrm{~N} \mathrm{ha}^{-1} \mathrm{yr}^{-1}\right)$. Hereafter, treatments will be denoted as: $\mathrm{N}_{0}, \mathrm{~N}_{10}, \mathrm{~N}_{20}, \mathrm{~N}_{40}, \mathrm{~N}_{60}, \mathrm{~N}_{80}$, $\mathrm{N}_{100}, \mathrm{~N}_{120}$, and $\mathrm{N}_{140}$. At the first day of every month, 71.42, 142.85, $214.27,285.69,357.12,428.54,499.96$, and $571.39 \mathrm{~g}$ of urea fertilizers (analytical reagent, $\mathrm{N}$ content of $46 \%$ ) were weighed and dissolved in 40 L of water and then were evenly sprayed onto corresponding $\mathrm{N}$ addition plots, and the control ones received equivalent water.

\subsection{Measurements of soil $\mathrm{N}_{2} \mathrm{O}$ flux and auxiliary variables}

Three permanent chamber bases (area $0.25 \mathrm{~m}^{2}$, height $15 \mathrm{~cm}$, $\sim 10 \mathrm{~cm}$ inserted into the soil) were randomly installed on each plot. Over the growing seasons (from May to October) of 2013, the soil $\mathrm{N}_{2} \mathrm{O}$ fluxes were determined using the static chamber and gas chromatography technique. Five gas samples ( $100 \mathrm{~mL}$ each) were removed at 0,10 , 20,30 , and 40 min after chamber closure and stored in pre-evacuated glass containers with a teflon-coated stopcock. Gas samples were analyzed using a gas chromatograph (Agilent 7890A, Santa Clara, California, USA) equipped with an electron capture detector and an autosampler. $\mathrm{N}_{2} \mathrm{O}$ concentrations were determined by comparison of integrated peak areas of samples and five standard gases (320, 550, 1010, 1500, and $2300 \mathrm{ppb} \mathrm{N}_{2} \mathrm{O}$ ). $\mathrm{N}_{2} \mathrm{O}$ fluxes were calculated from the linear increase of gas concentration in the chamber vs. time, and were adjusted for air temperature and atmospheric pressure measured at the time of sampling (Zheng et al., 2008). During the same time as the gas samples were collected, soil temperature and soil moisture at $10 \mathrm{~cm}$ below soil surface were monitored at each chamber using portable temperature probes (JM624 digital thermometer, Living-Jinming Ltd., China) and a moisture probe meter (TDR100, Spectrum, USA), respectively.

\subsection{Measurements of soil dissolved $N$ concentrations}

After gas samples were collected, soils in litter layer (Oe/Oa) and 0$10 \mathrm{~cm}$ mineral layer (A) were taken using a $2.5 \mathrm{~cm}$ diameter auger. Five random cores were sampled at each plot, and then pooled for one sample. Soil samples were immediately passed through a $2-\mathrm{mm}$ sieve to remove roots, gravel and stones, and then were transported to the laboratory in chilled polystyrene boxes. Soils were extracted using $2 \mathrm{M}$ $\mathrm{KCl}$ for $\mathrm{NH}_{4}^{+}, \mathrm{NO}_{3}^{-}$, and total dissolved $\mathrm{N}$ (TDN) within a week to minimize storage effects on mineral $\mathrm{N}$ pools. Approximately $15 \mathrm{~g}$ fresh soil plus $100 \mathrm{~mL}$ of $2 \mathrm{M} \mathrm{KCl}$ were weighed into polyethylene bottles and shaken for $1 \mathrm{~h}$. The soil solution was filtered using Whatman \#1 filters, and the extracts were immediately frozen. Soil $\mathrm{NH}_{4}^{+}-\mathrm{N}, \mathrm{NO}_{3}^{-}-\mathrm{N}$, and TDN concentrations were determined by colorimetry on a continuous flow Auto Analyzer (AA3, SEAL, Germany). Because $\mathrm{NO}_{2}^{-}$in soil extracts is unstable and easily changed to $\mathrm{NO}_{3}^{-}$, it was not determined in this study. Therefore, we approximately thought that dissolved organic nitrogen (DON) was equal to the difference between TDN and total inorganic $\mathrm{N}\left(\mathrm{NH}_{4}^{+}-\mathrm{N}\right.$ and $\left.\mathrm{NO}_{3}^{-}-\mathrm{N}\right)$.

\subsection{Statistical analyses}

Repeated measures analysis of variance (ANOVA) was applied to examine the differences of soil temperature, soil moisture, dissolved $\mathrm{N}$ concentrations, and soil $\mathrm{N}_{2} \mathrm{O}$ fluxes for different rates of $\mathrm{N}$ addition. Comparisons of the means were conducted using Tukey's honestly significant difference test. Stepwise regression analysis was used to examine the relationships between soil $\mathrm{N}_{2} \mathrm{O}$ fluxes and other measured variables. Also, linear regression was used to elucidate the relationships between the changes in soil $\mathrm{N}_{2} \mathrm{O}$ fluxes ( $\Delta$ soil $\mathrm{N}_{2} \mathrm{O}$ fluxes) and the 
Table 1

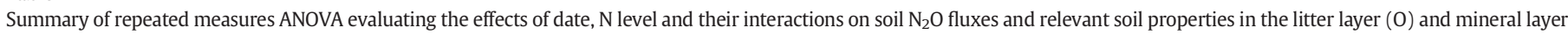
(M).

\begin{tabular}{|c|c|c|c|c|c|c|c|c|c|c|c|}
\hline & \multirow[t]{2}{*}{$\mathrm{Ts}^{\mathrm{a}}$} & \multirow[t]{2}{*}{$M s^{\mathrm{a}}$} & \multirow[t]{2}{*}{$\mathrm{N}_{2} \mathrm{O}$ flux } & \multicolumn{2}{|l|}{$\mathrm{NH}_{4}^{+}-\mathrm{N}$} & \multicolumn{2}{|l|}{$\mathrm{NO}_{3}^{-}-\mathrm{N}$} & \multicolumn{2}{|l|}{$\mathrm{DON}^{\mathrm{a}}$} & \multicolumn{2}{|l|}{$\mathrm{TDN}^{\mathrm{a}}$} \\
\hline & & & & 0 & M & 0 & M & 0 & M & 0 & M \\
\hline \multicolumn{12}{|l|}{ Between subjects } \\
\hline $\mathrm{N}$ level & 0.99 & $<0.001$ & 0.001 & 0.029 & 0.30 & $<0.001$ & $<0.001$ & 0.005 & 0.73 & $<0.001$ & 0.38 \\
\hline \multicolumn{12}{|l|}{ Within subjects } \\
\hline Date & $<0.001$ & $<0.001$ & $<0.001$ & $<0.001$ & $<0.001$ & $<0.001$ & $<0.001$ & $<0.001$ & $<0.001$ & $<0.001$ & $<0.001$ \\
\hline Date $\times \mathrm{N}$ level & 0.99 & 0.45 & 0.49 & 0.020 & 0.98 & 0.58 & 0.39 & 0.98 & 0.99 & 0.074 & 0.94 \\
\hline
\end{tabular}

a Ts, Ms, DON, TDN are $10 \mathrm{~cm}$ soil temperature, $10 \mathrm{~cm}$ soil moisture, dissolved organic nitrogen, and total dissolved nitrogen, respectively.

changes in soil variables ( $\Delta$ soil variables) among the treatments in two soil layers. All statistical analyses were conducted using the SPSS software package (version 16.0) and graphics were drawn using the SigmaPlot software (version 12.5). Statistical significant differences were set with $P$ values $=0.05$.

\section{Results}

\subsection{Soil temperature, moisture, and $\mathrm{N}_{2} \mathrm{O}$ flux}

Soil temperature in $0-10 \mathrm{~cm}$ depth showed a single-peak variation, with the peak occurring in early August $(P<0.001$, Table 1, Fig. 1a). Soil temperature in $0-10 \mathrm{~cm}$ depth, ranging from $5.9{ }^{\circ} \mathrm{C}$ to $18.7^{\circ} \mathrm{C}$, was not influenced by $\mathrm{N}$ addition (Fig. 1b, Table 1). Soil moisture in 0 $10 \mathrm{~cm}$ depth exhibited significant "event" characteristics three peaks in soil moisture content in early June, early September, and later October, corresponding to the period of snowmelt in June, and rain and snow events in September and October, respectively $(P<0.001$, Table 1, Fig. 1c). Soil moisture averaged $35.4 \%$ in the control plots, and N addition at the rates of $>80 \mathrm{~kg} \mathrm{~N} \mathrm{ha}^{-1} \mathrm{yr}^{-1}\left(\mathrm{~N}_{80}\right)$ significantly increased soil
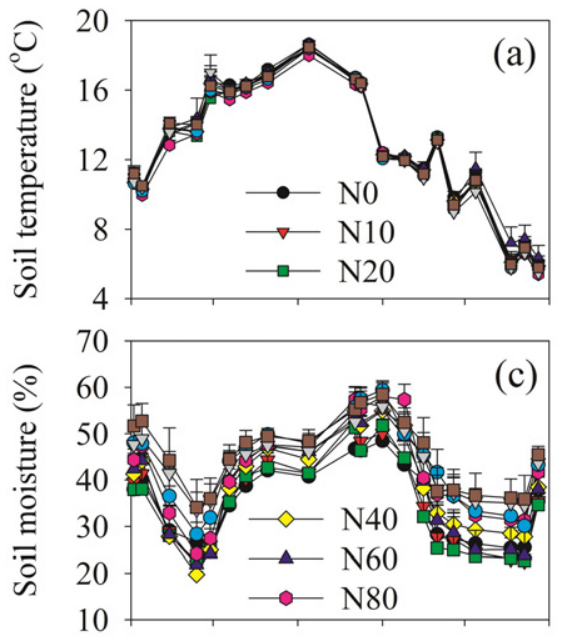

(c)

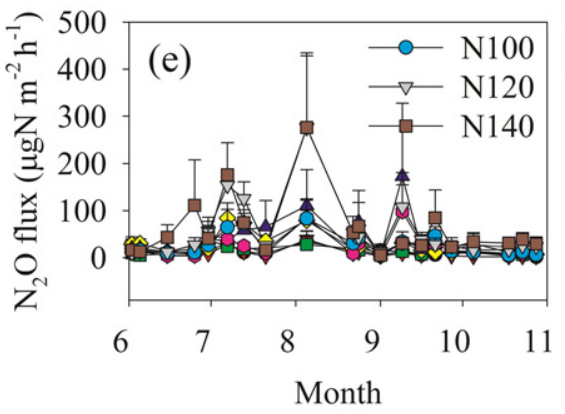

moisture by $17.75 \%$ to $28.49 \%$ (Fig. 1d). Also, there was significant seasonality for soil $\mathrm{N}_{2} \mathrm{O}$ flux with a peak occurring in early August $\left(P<0.001\right.$, Table 1, Fig. 1e). Soil $\mathrm{N}_{2} \mathrm{O}$ flux averaged $13.75 \mu \mathrm{g} \mathrm{N} \mathrm{ha}^{-1} \mathrm{yr}^{-1}$ at the control plots, and $\mathrm{N}$ addition significantly increased soil $\mathrm{N}_{2} \mathrm{O}$ flux by $194 \%, 297 \%$, and $334 \%$ at the $\mathrm{N}_{60}, \mathrm{~N}_{120}$, and $\mathrm{N}_{140}$, respectively (Fig. $1 \mathrm{f}$ ). Overall, soil $\mathrm{N}_{2} \mathrm{O}$ flux grew exponentially with increase in the rates of $\mathrm{N}$ addition $\left(\mathrm{R}^{2}=0.89, P=0.001\right.$, Fig. $\left.1 \mathrm{f}\right)$.

\subsection{Soil dissolved $N$ concentrations}

The seasonal variations of soil $\mathrm{NO}_{3}^{-}-\mathrm{N}, \mathrm{NH}_{4}^{+}-\mathrm{N}, \mathrm{DON}$, and TDN in litter layer were significant $(P<0.001$, Table 1 , Fig. 2$)$. The peaks of soil $\mathrm{NO}_{3}^{-}-\mathrm{N}, \mathrm{NH}_{4}^{+}-\mathrm{N}, \mathrm{DON}$, and TDN in litter layer occurred in later October, early August, mid-June, and later October, respectively (Fig. 2). In the control plots, soil $\mathrm{NO}_{3}^{-}-\mathrm{N}, \mathrm{NH}_{4}^{+}-\mathrm{N}$, and DON concentration averaged $52.99 \mathrm{mg} \mathrm{kg}^{-1}, 275.0 \mathrm{mg} \mathrm{kg}^{-1}$, and $118.89 \mathrm{mg} \mathrm{kg}^{-1}$, accounting for $12.13 \%, 62.95 \%$, and $27.22 \%$ of soil TDN content, respectively (Fig. $2 \mathrm{~b}$, $\mathrm{d}$, and $\mathrm{f}$ ). High rates of $\mathrm{N}$ addition ( $>80 \mathrm{~kg} \mathrm{~N} \mathrm{ha}^{-1} \mathrm{yr}^{-1}$ ) consistently and significantly increased soil $\mathrm{NO}_{3}^{-}-\mathrm{N}$ and TDN concentrations in litter layer by $120 \%-180 \%$ and $33.4 \%-51.3 \%$, respectively (Fig. $2 \mathrm{~b}$ and $\mathrm{h}$ ).
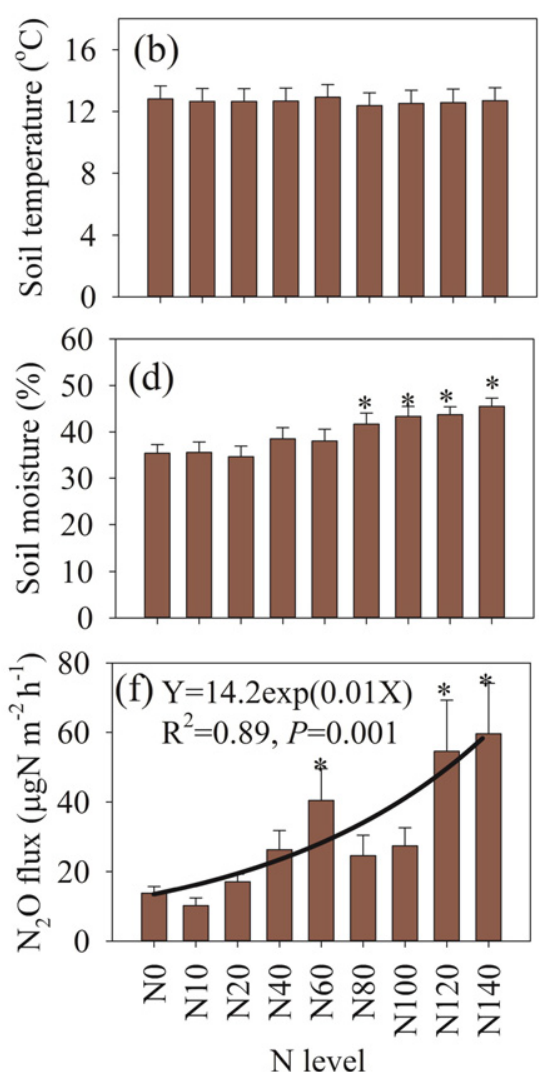

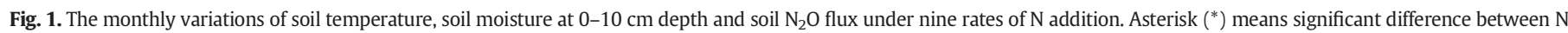
treatments and control at the level of 0.05 . 

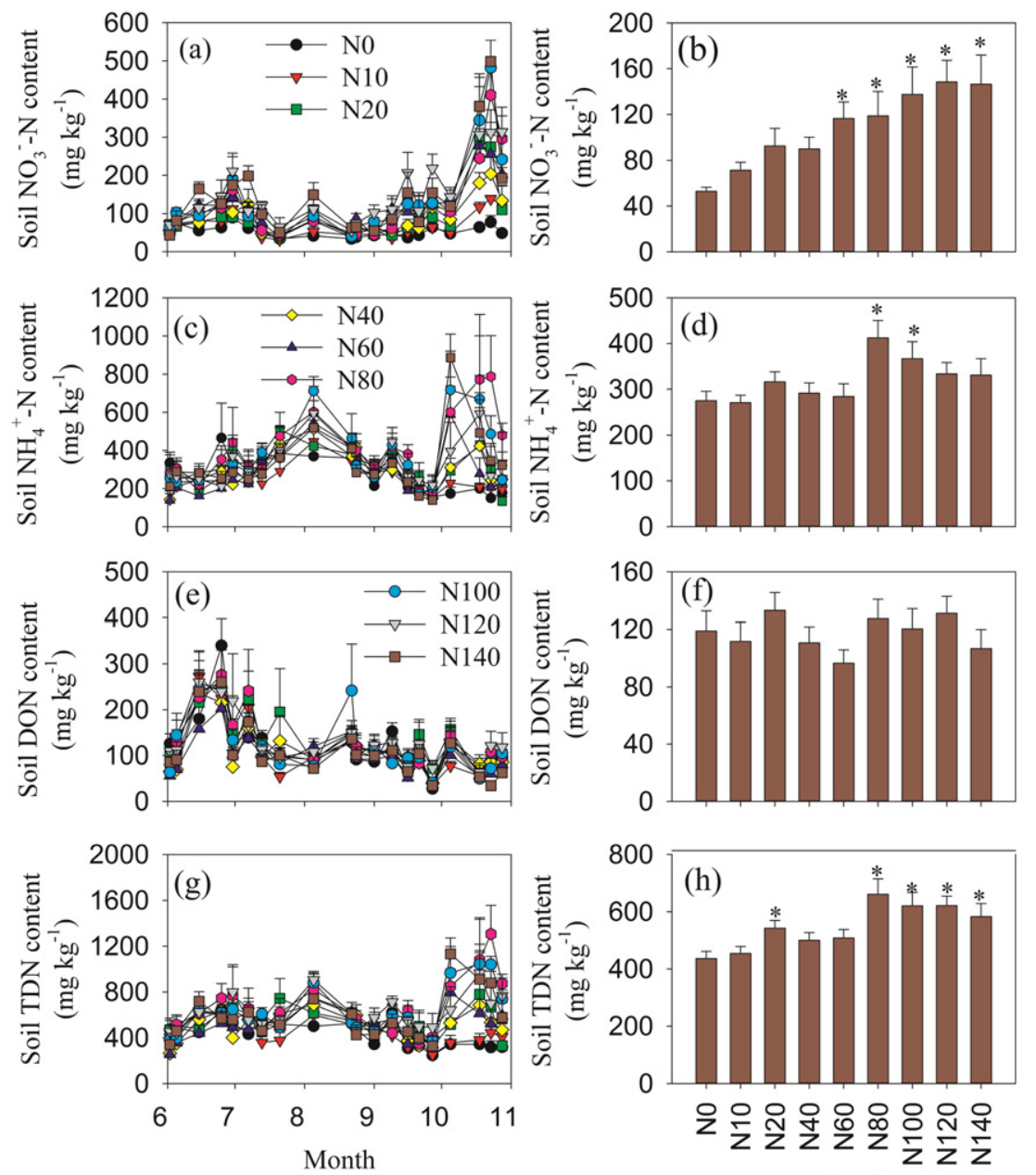

$\mathrm{N}$ level

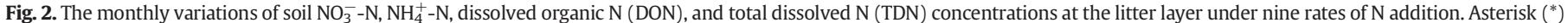
means significant difference between $\mathrm{N}$ treatments and control at the level of 0.05 .

However, $\mathrm{N}$ addition slightly increased soil $\mathrm{NH}_{4}^{+}-\mathrm{N}$ concentrations and did not change DON concentrations in litter layer (Table 1, Fig. 2d, and f).

There were significant seasonal variations in the three soil dissolved $\mathrm{N}$ in mineral layer with an obvious peak occurring in mid-July $\left(P<0.001\right.$, Table 1, Fig. 3). Under nature conditions, the soil $\mathrm{NH}_{4}^{+}-\mathrm{N}$, $\mathrm{NO}_{3}^{-}-\mathrm{N}$, DON and TDN concentrations were lower in mineral layer than in litter layer, the former were 6.9-14.5 times as high as the latter (Figs. 2 and 3). $\mathrm{N}$ addition only led to significant accumulations of soil $\mathrm{NO}_{3}^{-}-\mathrm{N}$ contents $(P<0.001$, Table 1 , Fig. 3b). No significant differences were observed in another three soil dissolved $\mathrm{N}$ contents across different $\mathrm{N}$ addition levels (Table 1, Fig. 3d, f, and h).

\subsection{Relationships between soil $\mathrm{N}_{2} \mathrm{O}$ fluxes and soil variables}

The relationship between soil $\mathrm{N}_{2} \mathrm{O}$ fluxes and soil temperature could be characterized by an exponential growth equation (Table 2, Fig. 4a). The relationships between soil $\mathrm{N}_{2} \mathrm{O}$ fluxes, soil moisture, soil DON, and TDN concentrations could be well fitted by modified Gaussian equations (Fig. 4b, d, and f), and the critical values at the peak of the regression equation were $45.55 \%, 91.42 \mathrm{mg} \mathrm{kg}^{-1}$, and $399.60 \mathrm{mg} \mathrm{kg}^{-1}$, respectively (Table 2). Also, soil $\mathrm{N}_{2} \mathrm{O}$ fluxes were positively and linearly correlated with soil moisture, soil $\mathrm{NH}_{4}^{+}-\mathrm{N}$ and $\mathrm{NO}_{3}^{-}-\mathrm{N}$ concentrations (Table 2, Fig. $4 \mathrm{c}$, and e). Multiple stepwise regression analysis revealed that soil $\mathrm{N}_{2} \mathrm{O}$ fluxes were mainly controlled by soil temperature, followed by soil
$\mathrm{NO}_{3}^{-}-\mathrm{N}$ and moisture (Table 2). They together explained $>36 \%$ of the temporal variation in soil $\mathrm{N}_{2} \mathrm{O}$ flux (Table 2 ).

To evaluate the relative contribution of each soil variable to the change in soil $\mathrm{N}_{2} \mathrm{O}$ flux elicited by $\mathrm{N}$ addition, we performed a simple regression analysis of the data. The net change in soil $\mathrm{N}_{2} \mathrm{O}$ flux $\left(\Delta\right.$ soil $\mathrm{N}_{2} \mathrm{O}$ flux, $\mathrm{N}$ addition treatments relative to the control) was positively correlated with the changes of soil $\mathrm{NO}_{3}^{-}-\mathrm{N}$ and soil moisture $\left(\Delta\right.$ soil $\mathrm{NO}_{3}^{-}-\mathrm{N}$ content and $\Delta$ soil moisture); moreover, the correlation coefficient of the former was higher than that of the latter (Fig. 5).

\section{Discussion}

\subsection{The responses of soil $\mathrm{N}_{2} \mathrm{O}$ flux to $\mathrm{N}$ addition}

Under natural conditions, the temperate broadleaf and mixed forest soil acted as a weak source for $\mathrm{N}_{2} \mathrm{O}\left(13.75 \pm 1.97 \mu \mathrm{g} \mathrm{N} \mathrm{m}{ }^{-2} \mathrm{~h}^{-1}\right.$, Fig. 1f), which is higher than the measurements in the temperate pine and hardwood forests of North America $\left(0.27-1.10 \mu \mathrm{g} \mathrm{N} \mathrm{m}{ }^{-2} \mathrm{~h}^{-1}\right.$, Bowden et al., 1991), as well as in European hardwood forests $\left(3-11 \mu \mathrm{g} \mathrm{N} \mathrm{m}^{-2} \mathrm{~h}^{-1}\right.$ ) (Schmidt et al., 1988). The reason for the observed differences might be ascribed to the $\mathrm{N}$ status of the forests and the capacity for nitrification between the stands. In this study, we found that $\mathrm{N}$ addition at levels of $<60 \mathrm{~kg} \mathrm{~N} \mathrm{ha}^{-1} \mathrm{yr}^{-1}$ did not influence soil $\mathrm{N}_{2} \mathrm{O}$ flux, while high $\mathrm{N}\left(\mathrm{N}_{60}\right.$, $\mathrm{N}_{120}, \mathrm{~N}_{140}$ ) significantly increased soil $\mathrm{N}_{2} \mathrm{O}$ flux (Fig. 1e-f). These results, to a certain extent, supported our first hypothesis that organic $\mathrm{N}$ 

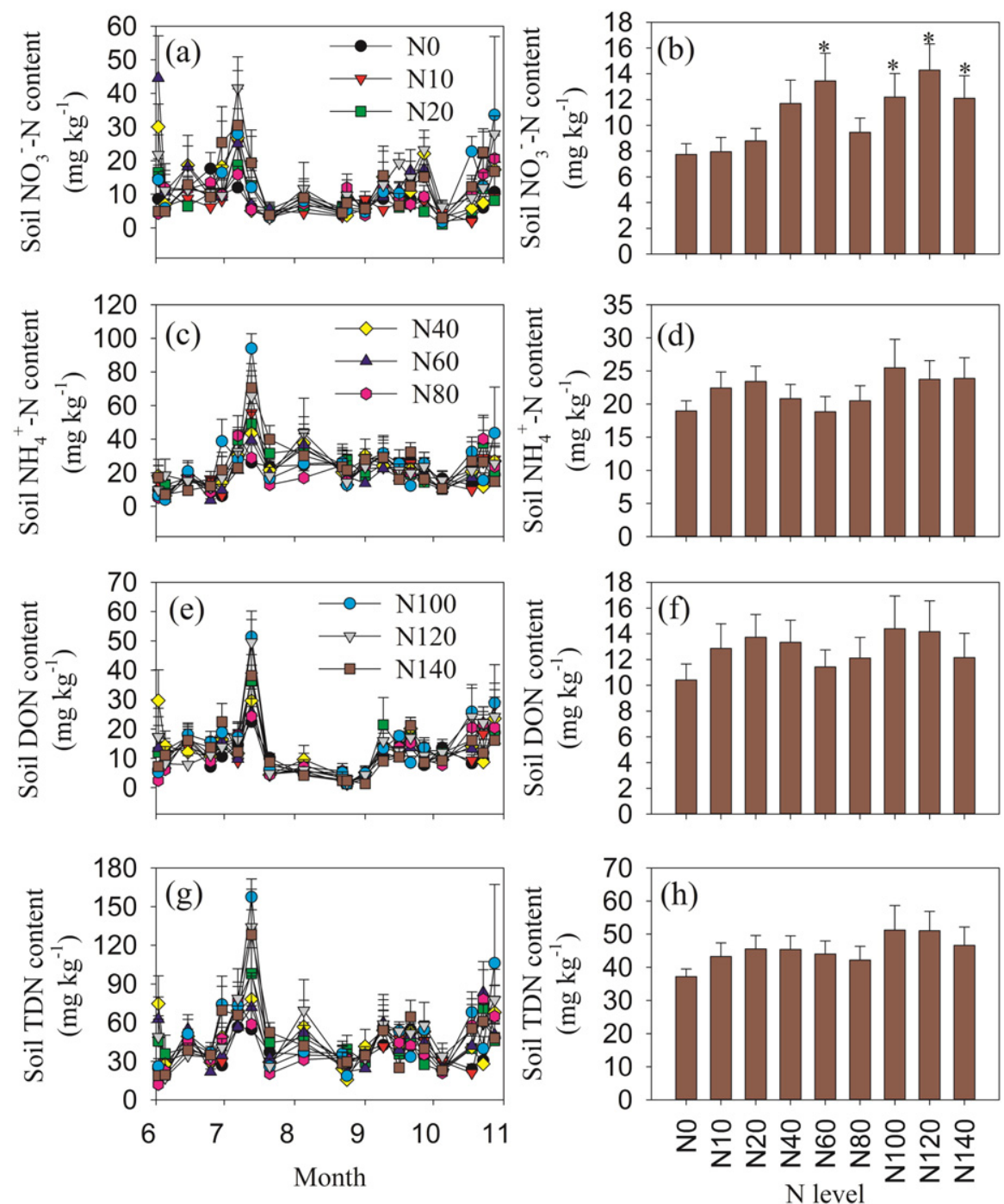

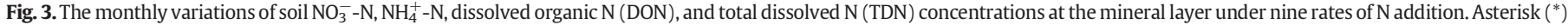
means significant difference between $\mathrm{N}$ treatments and control at the level of 0.05 .

addition did not promote $\mathrm{N}_{2} \mathrm{O}$ emission from the $\mathrm{N}$-poor temperate forest soil until $\mathrm{N}$ addition rate exceeded its critical level. Soil $\mathrm{N}_{2} \mathrm{O}$ flux grew exponentially with the rates of $\mathrm{N}$ addition, which was consistent with several studies in the forest, grassland, and cropland ecosystems (Ambus et al., 2006; Liu et al., 2013a, 2013b; Liu et al., 2015). The critical level of $\mathrm{N}$ input for the significant promotion of soil $\mathrm{N}_{2} \mathrm{O}$ emission was approximately $70 \mathrm{~kg} \mathrm{~N} \mathrm{ha}^{-1} \mathrm{yr}^{-1}$ while taking the ambient $\mathrm{N}$ deposition rate of $10 \mathrm{~kg} \mathrm{~N} \mathrm{ha}^{-1} \mathrm{yr}^{-1}$ into account (Zhu et al., 2015). Because soil $\mathrm{NO}_{3}^{-}-\mathrm{N}$ content largely dominated the change of soil $\mathrm{N}_{2} \mathrm{O}$ emission caused by $\mathrm{N}$ enrichment (Fig. 5a), the critical value of soil $\mathrm{NO}_{3}^{-}-\mathrm{N}$

Table 2

Regression models between soil $\mathrm{N}_{2} \mathrm{O}$ fluxes and soil properties.

\begin{tabular}{lllr}
\hline Soil variables $^{\mathrm{a}}$ & Regression equation & $\mathrm{R}^{2}$ & $P$ value \\
\hline $\mathrm{Ts}$ & $\mathrm{F}_{\mathrm{N} 2 \mathrm{O}}=1.25 \exp (0.23 \mathrm{Ts})$ & 0.20 & $<0.001$ \\
$\mathrm{Ms}$ & $\mathrm{F}_{\mathrm{N} 2 \mathrm{O}}=48.47 \exp [-0.5 * \mathrm{abs}(\mathrm{Ms}-45.55) / 7.50]$ & 0.12 & $<0.001$ \\
$\mathrm{NO}_{3}^{-}-\mathrm{N}$ & $\mathrm{F}_{\mathrm{N} 2 \mathrm{O}}=7.37+0.49 \mathrm{NO}_{3}^{-}-\mathrm{N}$ & 0.11 & $<0.001$ \\
$\mathrm{NH}_{4}^{+}-\mathrm{N}$ & $\mathrm{F}_{\mathrm{N} 2 \mathrm{O}}=-5.11+0.23 \mathrm{NH}_{4}^{+}-\mathrm{N}$ & 0.099 & $<0.001$ \\
$\mathrm{DON}$ & $\mathrm{F}_{\mathrm{N} 2 \mathrm{O}}=54.21 \exp [-0.5 * \mathrm{abs}(\mathrm{DON}-91.42) / 26.55]$ & 0.052 & 0.012 \\
$\mathrm{TDN}$ & $\mathrm{F}_{\mathrm{N} 2 \mathrm{O}}=58.74 \exp [-0.5 * \mathrm{abs}(\mathrm{TDN}-399.6) / 86.87]$ & 0.10 & $<0.001$ \\
Combined & $\mathrm{F}_{\mathrm{N} 2 \mathrm{O}}=-96.30+4.43 \mathrm{Ts}+0.67 \mathrm{NO}_{3}^{-}-\mathrm{N}+0.82 \mathrm{Ms}$ & 0.36 & $<0.001$ \\
\hline
\end{tabular}

${ }^{a}$ Ts is soil temperature at $10 \mathrm{~cm}$ depth, Ms is soil moisture at $10 \mathrm{~cm}$ depth, $\mathrm{NH}_{4}^{+}, \mathrm{NO}_{3}^{-}$, and TDN are the average concentrations of soil $\mathrm{NH}_{4}^{+}, \mathrm{NO}_{3}^{-}$, and TDN at $20 \mathrm{~cm}$ depth. content was estimated to be $6.89 \mathrm{~g} \mathrm{~m}^{-2}$ if the average soil bulk density of $0.53 \mathrm{~g} \mathrm{~m}^{-3}$ was used for calculating (Wang et al., 2012). Therefore, we can assume that the exogenous $\mathrm{N}$ input at the level of $<70 \mathrm{~kg} \mathrm{~N} \mathrm{ha}^{-1} \mathrm{yr}^{-1}$ will not significantly stimulate soil $\mathrm{N}_{2} \mathrm{O}$ emission, but it is favorable to $\mathrm{C}$ sequestration of the temperate needle-broadleaved mixed forest, Northeast China.

The responses of soil $\mathrm{N}_{2} \mathrm{O}$ flux to $\mathrm{N}$ addition rates depend on the competitive interactions for soil available $\mathrm{N}$ between plants and soil microorganisms, and this competition includes three stages. First, plants are the winners for $\mathrm{N}$ acquisition in the long run compared with soil microbes (Kuzyakov and $\mathrm{Xu}, 2013$ ). So most of exogenous $\mathrm{N}$ could be absorbed by plants at low $\mathrm{N}$ concentrations and the activities of soil nitrifiers and denitrifiers are limited by available $\mathrm{N}$. $\mathrm{N}$ addition does not change or reduces soil available $\mathrm{N}$ contents and soil $\mathrm{N}_{2} \mathrm{O}$ emission (Aber et al., 1998; Borken and Beese, 2005). Second, after plant's N requirements are met, remaining available $\mathrm{N}$ is used by soil $\mathrm{N}$ nitrifying and denitrifying bacteria. Soil $\mathrm{N}_{2} \mathrm{O}$ emission linearly increases with the increasing rate of $\mathrm{N}$ addition (Repo et al., 2009). Third, with the further accumulation of soil available $\mathrm{N}$ elicited by exogenous $\mathrm{N}$ input, $\mathrm{N}_{2} \mathrm{O}$-producing microbes can be stimulated and a higher percentage of available $\mathrm{N}$ is released in the form of $\mathrm{N}_{2} \mathrm{O}$ (McSwiney and Robertson, 2005). At this time, soil $\mathrm{N}_{2} \mathrm{O}$ emission grows exponentially with the increasing rate of $\mathrm{N}$ addition. For a given ecosystem, the observed response curve of soil $\mathrm{N}_{2} \mathrm{O}$ flux to $\mathrm{N}$ addition should demonstrate one stage of the three. 

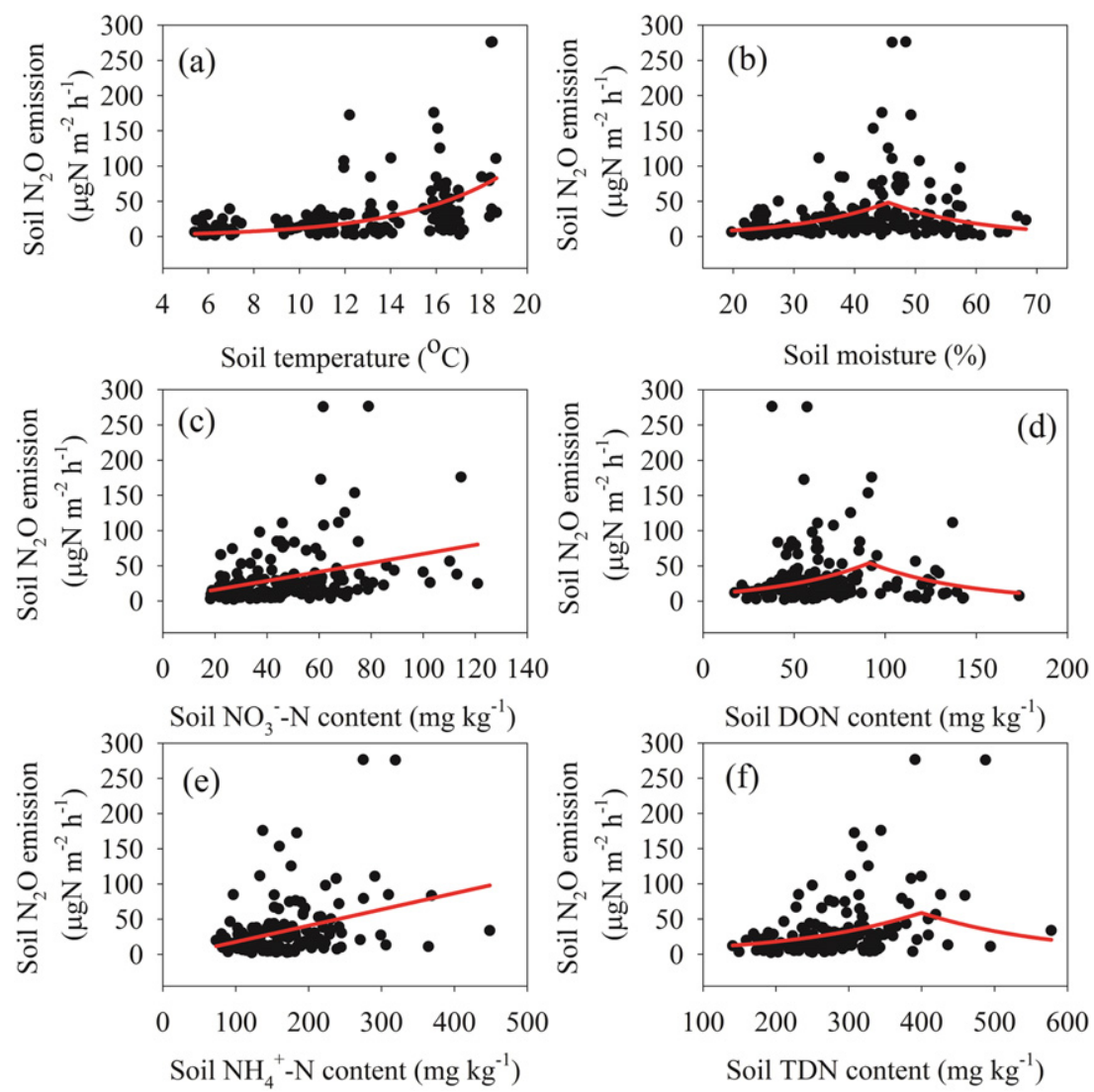

Fig. 4. The relationships between soil $\mathrm{N}_{2} \mathrm{O}$ fluxes and related soil properties (soil temperature, soil moisture, and dissolved $\mathrm{N}$ concentrations).

\subsection{The main processes controlling soil $\mathrm{N}_{2} \mathrm{O}$ production}

An exponential growth equation and a linear equation could be used to fit the relationships between the soil $\mathrm{N}_{2} \mathrm{O}$ fluxes and soil temperature and between the soil $\mathrm{N}_{2} \mathrm{O}$ fluxes and soil moisture, respectively (Fig. 4). Soil water content has a direct effect on oxygen availability due to its
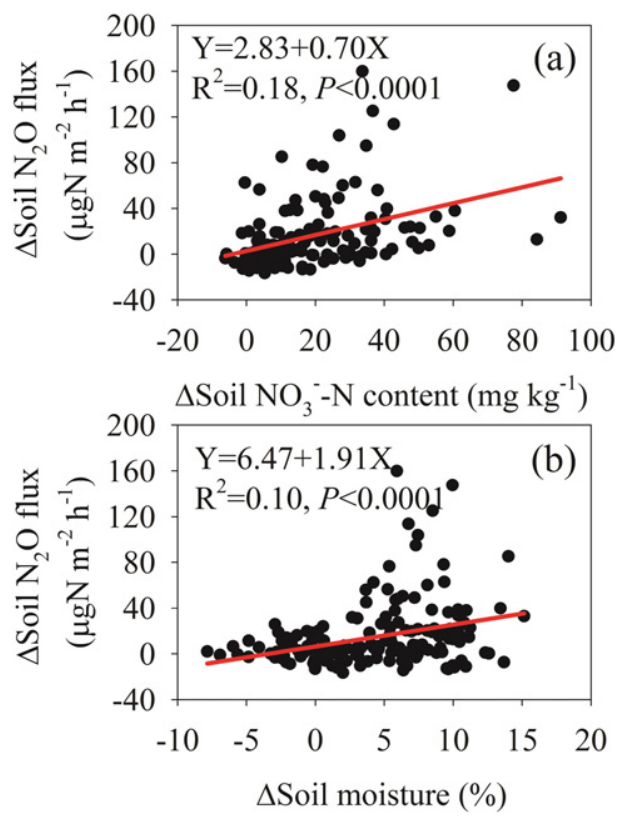

Fig. 5. The relationships between the changes in soil $\mathrm{N}_{2} \mathrm{O}$ fluxes and the changes in soil $\mathrm{NO}_{3}^{-}-\mathrm{N}$ concentrations and soil moisture contents caused by $\mathrm{N}$ addition. effect on oxygen diffusion whereas soil temperature indirectly controls the oxygen status through its effect on microbial activity and thus, oxygen consumption (Ding et al., 2007). Soil moisture and temperature are often reported to explain most of the variation in $\mathrm{N}_{2} \mathrm{O}$ fluxes in European forests (e.g., Schindlbacher et al., 2004; Pilegaard et al., 2006) even in forests highly enriched in N (Brumme et al., 1999). Also, nitrifying and denitrifying bacteria are quite sensitive to soil temperature and moisture, which fundamentally determines the nitrification and denitrification rates (Butterbach-Bahl et al., 2013). The cold and moist climate in the temperate needle-broadleaved mixed forest may favor nitrification and denitrification, and consequently $\mathrm{N}_{2} \mathrm{O}$ emissions, regardless of abundant $\mathrm{NH}_{4}^{+}$and $\mathrm{NO}_{3}^{-}$substrates (Eickenscheidt and Brumme, 2012). However, soil hydrothermal factors and soil dissolved $\mathrm{N}$ contents only explained $36 \%$ of the variation of soil $\mathrm{N}_{2} \mathrm{O}$ flux, indicating that other environmental variables such as soil redox potential (Eh), water-filled pore space, $\mathrm{pH}$, and labile $\mathrm{C}$ content could have greater effects on soil $\mathrm{N}_{2} \mathrm{O}$ emission (Weier et al., 1993; Pilegaard et al., 2006). These factors often determine the abundance and composition of soil nitrifier and denitrifier communities (Wallenstein et al., 2006).

Moreover, $\mathrm{N}_{2} \mathrm{O}$ emissions are byproducts of nitrification $\left(\mathrm{NH}_{4}^{+} \rightarrow \mathrm{NO}_{3}^{-}\right)$and denitrification $\left(\mathrm{NO}_{3}^{-} \rightarrow \mathrm{N}_{2}\right)$, which rely on the availability of soil $\mathrm{NH}_{4}^{+}$and $\mathrm{NO}_{3}^{-}$. In our study, we also found significant and positive relationships between soil $\mathrm{N}_{2} \mathrm{O}$ fluxes and soil $\mathrm{NO}_{3}^{-}-\mathrm{N}$ contents, and between soil $\mathrm{N}_{2} \mathrm{O}$ fluxes and soil $\mathrm{NH}_{4}^{+}-\mathrm{N}$ contents, respectively (Fig. $4 \mathrm{c}$ and e), which indicated the increase in substrate availability of autotrophic nitrification and biological denitrification. The nonlinear relationships between soil DON contents and $\mathrm{N}_{2} \mathrm{O}$ emission suggested that there was an optimal substrate concentration (ca. $90 \mathrm{mg} \mathrm{kg}^{-1}$ ) for soil heterotrophic nitrification (Fig. 4d). Using ${ }^{15} \mathrm{~N}$ paired labeling and tracing model, Zhang et al. (2011) documents that heterotrophic nitrification of organic $\mathrm{N}$ is the predominant $\mathrm{NO}_{3}^{-}$production pathway in the temperate forest soils in Northeast China. Therefore, heterotrophic nitrification could have a greater contribution to soil $\mathrm{N}_{2} \mathrm{O}$ production than 
autotrophic nitrification under aerobic conditions (Zhu et al., 2011). Stepwise linear regression analysis showed that soil temperature, soil $\mathrm{NO}_{3}^{-}-\mathrm{N}$ content, and soil moisture content were the dominant factors that controlled soil $\mathrm{N}_{2} \mathrm{O}$ emissions (Table 2). Ambus et al. (2006) reports that $\mathrm{NO}_{3}^{-}-\mathrm{N}$ is the major substrate for soil $\mathrm{N}_{2} \mathrm{O}$ production in European temperate forests with the average contribution of $62 \%$, whereas soil $\mathrm{NH}_{4}^{+}-\mathrm{N}$ can explain $34 \%$ of the variation of soil $\mathrm{N}_{2} \mathrm{O}$ flux. Since $\mathrm{NO}_{3}^{-}-\mathrm{N}$ was either produced by net or by gross nitrification, $\mathrm{NO}_{3}^{-}-\mathrm{N}$ accumulated in soils may have become the exclusive source for denitrification and $\mathrm{N}_{2} \mathrm{O}$ production. In our study, the net changes in soil $\mathrm{N}_{2} \mathrm{O}$ fluxes caused by $\mathrm{N}$ addition were related to the net changes in soil $\mathrm{NO}_{3}^{-}-\mathrm{N}$ content and soil moisture content (Fig. 5), which indicated that the increase in soil $\mathrm{N}_{2} \mathrm{O}$ emission in the temperate needle-broadleaved forest under $\mathrm{N}$ enrichment could be mainly attributed to the increase in soil nitrification and denitrification. Similarly, based on the ${ }^{15} \mathrm{~N}$-tracing experiment, Cheng et al. (2014) suggests that the increase in $\mathrm{N}_{2} \mathrm{O}$ emission following $\mathrm{N}$ fertilizer application is attributed to increased heterotrophic and autotrophic nitrification rates and an increased ratio of $\mathrm{N}_{2} \mathrm{O}$ emission from denitrification.

\section{Conclusions}

The responses of soil $\mathrm{N}_{2} \mathrm{O}$ fluxes as well as soil dissolved $\mathrm{N}$ to $\mathrm{N}$ addition in a broadleaf and mixed forest were examined in the growing season of 2013 with an urea addition trail, including nine $\mathrm{N}$ rates $(0,10,20$, $40,60,80,100,120$ and $140 \mathrm{~kg} \mathrm{~N} \mathrm{ha}^{-1} \mathrm{yr}^{-1}$ ). Low $\mathrm{N}$ addition did not change but high $\mathrm{N}$ addition significantly led to the accumulation of soil $\mathrm{NO}_{3}^{-}-\mathrm{N}$ in both the litter layer and surface mineral layer. Soil $\mathrm{N}_{2} \mathrm{O}$ flux grew exponentially with increase in the rates of $\mathrm{N}$ addition. Taking the ambient $\mathrm{N}$ deposition rate of $10 \mathrm{~kg} \mathrm{~N} \mathrm{ha}^{-1} \mathrm{yr}^{-1}$ into account, we found that the critical level of $\mathrm{N}$ input for the significant alternation of soil dissolved $\mathrm{N}$ and soil $\mathrm{N}_{2} \mathrm{O}$ emission in the studied forest was around $70 \mathrm{~kg} \mathrm{~N} h a^{-1} \mathrm{yr}^{-1}$. The increase in soil $\mathrm{N}_{2} \mathrm{O}$ emission in the temperate needle-broadleaved mixed forest under $\mathrm{N}$ enrichment was mainly attributed to the increases in soil heterotrophic nitrification and biological denitrification. Unfortunately, we were unable to quantify the relative contributions of soil nitrification and denitrification to soil $\mathrm{N}_{2} \mathrm{O}$ flux due to some technical limitations such as ${ }^{15} \mathrm{~N}$ labeling, product isolation, measurement accuracy, etc.; moreover, the potential mechanisms involved in the formation of critical load for $\mathrm{N}$ retention are not clear. Further study is needed to simultaneously measure the rates of gross $\mathrm{N}$ transformation, and the abundance and composition of producing$\mathrm{N}_{2} \mathrm{O}$ microbial community in ambient and $\mathrm{N}$ enrichment soils. This would help to understand the mechanisms involved in the nonlinear responses of soil $\mathrm{N}_{2} \mathrm{O}$ emission to increased $\mathrm{N}$ deposition.

\section{Acknowledgements}

This research was funded by the Major State Research Development Program of China (No. 2016YFC0500603, 2016YFC0503603), Youth Innovation Research Team Project (LENOM2016Q0004) and National Natural Science Foundation of China (No. 31290222, 31290221, 41471212, 31470558, 31130009).

\section{References}

Aber, J., McDowell, W., Nadelhoffer, K., Magill, A., Berntson, G., Kamakea, M., McNulty, S., Currie, W., Rustad, L., Fernandez, I., 1998. Nitrogen saturation in temperate forest ecosystems. Bioscience 921-934.

Ambus, P., Zechmeister-Boltenstern, S., Butterbach-Bahl, K., 2006. Sources of nitrous oxide emitted from European forest soils. Biogeosciences 3, 135-145.

Bai, E., Li, W., Li, S., Sun, J., Peng, B., Dai, W., Jiang, P., Han, S., 2014. Pulse increase of soil $\mathrm{N}_{2} \mathrm{O}$ emission in response to $\mathrm{N}$ addition in a temperate forest on Mt Changbai, Northeast China. PLoS One 9, e102765. http://dx.doi.org/10.1371/journal.pone.0102765.

Bobbink, R., Hettelingh, J.P., 2011. Review and revisions of empirical critical loads and dose-response relationships. RIVM Report 680359002. Coordination Centre for Effects, National Institute for Public Health and the Environment (RIVM), Bilthoven, The Netherlands www.rivm.nl/cce.
Borken, W., Beese, F., 2005. Control of nitrous oxide emissions in European beech, Norway spruce and Scots pine forests. Biogeochemistry 76, 141-159.

Bowden, R.D., Melillo, J.M., Steudler, P.A., Aber, J.D., 1991. Effects of nitrogen additions on annual nitrous oxide fluxes from temperate forest soils in the northeastern United States. J. Geophys. Res. Atmos. 96, 9321-9328.

Brumme, R., Borken, W., Finke, S., 1999. Hierarchical control on nitrous oxide emission in forest ecosystems. Glob. Biogeochem. Cycles 13, 1137-1148.

Butterbach-Bahl, K. Baggs, E.M., Dannenmann, M., Kiese, R, Zechmeister-Boltenstern, S 2013. Nitrous oxide emissions from soils: how well do we understand the processes and their controls? Philos. Trans. R. Soc. B 368.

Cheng, Y., Wang, J., Wang, S.Q., Zhang, J.B., Cai, Z.C., 2014. Effects of soil moisture on gross $\mathrm{N}$ transformations and $\mathrm{N}_{2} \mathrm{O}$ emission in acid subtropical forest soils. Biol. Fertil. Soils 50, 1099-1108.

Davidson, E.A., 2009. The contribution of manure and fertilizer nitrogen to atmospheric nitrous oxide since 1860. Nat. Geosci. 2, 659-662.

Davidson, E.A., Keller, M., Erickson, H.E., Verchot, L.V., Veldkamp, E., 2000. Testing a conceptual model of soil emissions of nitrous and nitric oxides using two functions based on soil nitrogen availability and soil water content, the hole-in-the-pipe model characterizes a large fraction of the observed variation of nitric oxide and nitrous oxide emissions from soils. Bioscience 50, 667-680.

de Vries, W., Solberg, S., Dobbertin, M., Sterba, H., Laubhann, D., Van Oijen, M., Evans, C., Gundersen, P., Kros, J., Wamelink, G., 2009. The impact of nitrogen deposition on carbon sequestration by European forests and heathlands. For. Ecol. Manag. 258, 1814-1823.

Ding, W.X., Meng, L., Cai, Z.C., Han, F.X., 2007. Effects of long-term amendment of organic manure and nitrogen fertilizer on nitrous oxide emission in a sandy loam soil. J. Environ. Sci. (China) 19, 185-193.

Eickenscheidt, N., Brumme, R., 2012. $\mathrm{NO}_{\mathrm{x}}$ and $\mathrm{N}_{2} \mathrm{O}$ fluxes in a nitrogen-enriched European spruce forest soil under experimental long-term reduction of nitrogen depositions. Atmos. Environ. 60, 51-58.

Elberling, B., Christiansen, H.H., Hansen, B.U., 2010. High nitrous oxide production from thawing permafrost. Nat. Geosci. 3, 332-335.

Florinsky, I.V., McMahon, S., Burton, D.L., 2004. Topographic control of soil microbial activity: a case study of denitrifiers. Geoderma 119, 33-53.

Galloway, J.N., Townsend, A.R., Erisman, J.W., Bekunda, M., Cai, Z., Freney, J.R., Martinelli, L.A., Seitzinger, S.P., Sutton, M.A., 2008. Transformation of the nitrogen cycle: recent trends, questions, and potential solutions. Science 320, 889-892.

He, C.E., Liu, X., Fangmeier, A., Zhang, F., 2007. Quantifying the total airborne nitrogen input into agroecosystems in the North China Plain. Agric. Ecosyst. Environ. 121 395-400.

Hirsch, A., Michalak, A., Bruhwiler, L., Peters, W., Dlugokencky, E., Tans, P., 2006. Inverse modeling estimates of the global nitrous oxide surface flux from 1998-2001. Glob. Biogeochem. Cycles 20, GB1008. http://dx.doi.org/10.1029/2004GB002443.

Högberg, P., 2007. Environmental science: nitrogen impacts on forest carbon. Nature 447 $781-782$.

Jia, Y., Yu, G., He, N., Zhan, X., Fang, H., Sheng, W., Zuo, Y., Zhang, D., Wang, Q., 2014. Spatial and decadal variations in inorganic nitrogen wet deposition in China induced by human activity. Sci. Rep. 4, 3763. http://dx.doi.org/10.1038/srep03763.

Kim, Y.S., Imori, M., Watanabe, M., Hatano, R., Yi, M.J., Koike, T., 2012. Simulated nitrogen inputs influence methane and nitrous oxide fluxes from a young larch plantation in northern Japan. Atmos. Environ. 46, 36-44.

Kim, D.G., Hernandez-Ramirez, G., Giltrap, D., 2013. Linear and nonlinear dependency of direct nitrous oxide emissions on fertilizer nitrogen input: a meta-analysis. Agric Ecosyst. Environ. 168, 53-65.

Koehler, B., Corre, M.D., Veldkamp, E., Wullaert, H., Wright, S.J., 2009. Immediate and long-term nitrogen oxide emissions from tropical forest soils exposed to elevated nitrogen input. Glob. Chang. Biol. 15, 2049-2066.

Kuzyakov, Y., Xu, X.L., 2013. Competition between roots and microorganisms for nitrogen: mechanisms and ecological relevance. New Phytol. 198, 656-669.

Liu, L., Greaver, T.L., 2010. A global perspective on belowground carbon dynamics under nitrogen enrichment. Ecol. Lett. 13, 819-828.

Liu, C., Wang, K., Zheng, X., 2012. Responses of $\mathrm{N}_{2} \mathrm{O}$ and $\mathrm{CH}_{4}$ fluxes to fertilizer nitrogen addition rates in an irrigated wheat-maize cropping system in northern China. Biogeosciences 9, 839-850.

Liu, X., Zhang, Y., Han, W., Tang, A., Shen, J., Cui, Z., Vitousek, P., Erisman, J.W., Goulding, K, Christie, P., 2013a. Enhanced nitrogen deposition over China. Nature 494, 459-462.

Liu, Y., Xu, X., Wei, D., Wang, Y., Wang, Y., 2013b. Plant and soil responses of an alpine steppe on the Tibetan Plateau to multi-level nitrogen addition. Plant Soil 373, 515-529.

Liu, X., Dong, Y., Qi, Y., Peng, Q., He, Y., Sun, L., Jia, J., Guo, S., Cao, C., Yan, Z., 2015. Response of $\mathrm{N}_{2} \mathrm{O}$ emission to water and nitrogen addition in temperate typical steppe soil in Inner Mongolia, China. Soil Tillage Res. 151, 9-17.

Lü, C., Tian, H., 2007. Spatial and temporal patterns of nitrogen deposition in China: synthesis of observational data. J. Geophys. Res.-Atmos. 112, D22S05. http://dx.doi.org/ 10.1029/2006JD007990.

Lu, M., Yang, Y., Luo, Y., Fang, C., Zhou, X., Chen, J., Yang, X., Li, B., 2011a. Responses of ecosystem nitrogen cycle to nitrogen addition: a meta-analysis. New Phytol. 189, 1040-1050.

Lu, M., Zhou, X., Luo, Y., Yang, Y., Fang, C., Chen, J., Li, B., 2011b. Minor stimulation of soi carbon storage by nitrogen addition: a meta-analysis. Agric. Ecosyst. Environ. 140, 234-244.

Magnani, F., Mencuccini, M., Borghetti, M., Berbigier, P., Berninger, F., Delzon, S., Grelle, A Hari, P., Jarvis, P.G., Kolari, P., 2007. The human footprint in the carbon cycle of temperate and boreal forests. Nature $447,849-851$.

McSwiney, C.P., Robertson, G.P., 2005. Nonlinear response of $\mathrm{N}_{2} \mathrm{O}$ flux to incremental fertilizer addition in a continuous maize (Zea mays L.) cropping system. Glob. Chang. Biol. 11, 1712-1719. 
Pilegaard, K., Skiba, U., Ambus, P., Beier, C., Brüggemann, N., Butterbach-Bahl, K. Dick, J., Dorsey, J., Duyzer, J., Gallagher, M., 2006. Factors controlling regional differences in forest soil emission of nitrogen oxides ( $\mathrm{NO}$ and $\mathrm{N}_{2} \mathrm{O}$ ). Biogeosciences 3, 651-661.

Pinder, R.W., Bettez, N.D., Bonan, G.B., Greaver, T.L., Wieder, W.R., Schlesinger, W.H. Davidson, E.A., 2013. Impacts of human alteration of the nitrogen cycle in the US on radiative forcing. Biogeochemistry 114, 25-40.

Reay, D.S., Dentener, F., Smith, P., Grace, J., Feely, R.A., 2008. Global nitrogen deposition and carbon sinks. Nat. Geosci. 1, 430-437.

Repo, M.E., Susiluoto, S., Lind, S.E., Jokinen, S., Elsakov, V., Biasi, C., Virtanen, T. Martikainen, P.J., 2009. Large $\mathrm{N}_{2} \mathrm{O}$ emissions from cryoturbated peat soil in tundra. Nat. Geosci. 2, 189-192.

Rowlings, D., Grace, P., Kiese, R., Weier, K., 2012. Environmental factors controlling temporal and spatial variability in the soil-atmosphere exchange of $\mathrm{CO}_{2}, \mathrm{CH}_{4}$ and $\mathrm{N}_{2} \mathrm{O}$ from an Australian subtropical rainforest. Glob. Chang. Biol. 18, 726-738.

Schindlbacher, A., Zechmeister-Boltenstern, S., Butterbach-Bahl, K., 2004. Effects of soil moisture and temperature on $\mathrm{NO}, \mathrm{NO}_{2}$, and $\mathrm{N}_{2} \mathrm{O}$ emissions from European fores soils. J. Geophys. Res.-Atmos. 109, D17302. http://dx.doi.org/10.1029/2004JD004590.

Schmidt, J., Seiler, W., Conrad, R., 1988. Emission of nitrous oxide from temperate forest soils into the atmosphere. J. Atmos. Chem. 6, 95-115.

Skiba, U., Sheppard, L., Pitcairn, C., Van Dijk, S., Rossall, M., 1999. The Effect of N Deposition on Nitrous Oxide and Nitric Oxide Emissions From Temperate Forest Soils, Fores Growth Responses to the Pollution Climate of the 21st Century. Springer, pp. 89-98.

Solomon, S., 2007. Climate Change 2007 - The Physical Science Basis: Working Group I Contribution to the Fourth Assessment Report of the IPCC. Cambridge University Press.

Stocker, B.D., Roth, R., Joos, F., Spahni, R., Steinacher, M., Zaehle, S., Bouwman, L., Prentice, I.C., 2013. Multiple greenhouse-gas feedbacks from the land biosphere under future climate change scenarios. Nat. Clim. Chang. 3, 666-672.

Sutton, M.A., Simpson, D., Levy, P.E., Smith, R.I., Reis, S., Van Oijen, M., De Vries, W., 2008. Uncertainties in the relationship between atmospheric nitrogen deposition and forest carbon sequestration. Glob. Chang. Biol. 14, 2057-2063.

Templer, P., Mack, M., C. III, F., Christenson, L., Compton, J., Crook, H., Currie, W., Curtis, C., Dail, D., D'Antonio, C., 2012. Sinks for nitrogen inputs in terrestrial ecosystems: a meta-analysis of ${ }^{15} \mathrm{~N}$ tracer field studies. Ecology 93, 1816-1829.
Thomas, R.Q., Canham, C.D., Weathers, K.C., Goodale, C.L., 2010. Increased tree carbon storage in response to nitrogen deposition in the US. Nat. Geosci. 3, 13-17.

Wallenstein, M.D., Myrold, D.D., Firestone, M., Voytek, M., 2006. Environmental controls on denitrifying communities and denitrification rates: insights from molecular methods. Ecol. Appl. 16, 2143-2152.

Wang, C.G., Han, S.J., Zhou, Y.M., Yan, C.F., Cheng, X.B., Zheng, X.B., Li, M.H., 2012. Responses of fine roots and soil $\mathrm{N}$ availability to short-term nitrogen fertilization in a broad-leaved Korean pine mixed forest in Northeastern China. PLoS One 7, e31042. http://dx.doi.org/10.1371/journal.pon e.0031042.

Wang, Y., Cheng, S., Fang, H., Yu, G., Xu, M., Dang, X., Li, L., Wang, L., 2014. Simulated nitrogen deposition reduces $\mathrm{CH}_{4}$ uptake and increases $\mathrm{N}_{2} \mathrm{O}$ emission from a subtropical plantation forest soil in southern China. PLoS One 9, e93571. http://dx.doi.org/10. 1371/journal.pone.0093571.

Weier, K.L., Doran, J.W., Power, J.F., Walters, D.T., 1993. Denitrification and the dinitrogen/ nitrous oxide ratio as affected by soil water, available carbon, and nitrate. Soil Sci. Soc. Am. J. 57, 66-72.

Werner, C., Butterbach-Bahl, K., Haas, E., Hickler, T., Kiese, R., 2007. A global inventory of $\mathrm{N}_{2} \mathrm{O}$ emissions from tropical rainforest soils using a detailed biogeochemical model. Glob. Biogeochem. Cycles 21, GB3010. http://dx.doi.org/10.1029/2006GB002909.

Zhang, W., Mo, J., Yu, G., Fang, Y., Li, D., Lu, X., Wang, H., 2008. Emissions of nitrous oxide from three tropical forests in Southern China in response to simulated nitrogen deposition. Plant Soil 306, 221-236.

Zhang, J., Zhu, T., Cai, Z., Müller, C., 2011. Nitrogen cycling in forest soils across climate gradients in Eastern China. Plant Soil 342, 419-432.

Zheng, X., Mei, B., Wang, Y., Xie, B., Wang, Y., Dong, H., Xu, H., Chen, G., Cai, Z., Yue, J., 2008. Quantification of $\mathrm{N}_{2} \mathrm{O}$ fluxes from soil-plant systems may be biased by the applied gas chromatograph methodology. Plant Soil 311, 211-234.

Zhu, T., Zhang, J., Cai, Z., 2011. The contribution of nitrogen transformation processes to total $\mathrm{N}_{2} \mathrm{O}$ emissions from soils used for intensive vegetable cultivation. Plant Soil $343,313-327$.

Zhu, J., He, N., Wang, Q., Yuan, G., Wen, D., Yu, G., Jia, Y., 2015. The composition, spatial patterns, and influencing factors of atmospheric wet nitrogen deposition in Chinese terrestrial ecosystems. Sci. Total Environ. 511, 777-785. 